\title{
Chitosan-Based Thermo-Sensitive Hydrogel Loading Oyster Peptides for Hemostasis Application
}

\author{
Dongying Zhang ${ }^{1,2}$, Zhang $\mathrm{Hu}{ }^{1}, * \mathbb{D}$, Lingyu Zhang ${ }^{1}$, Sitong Lu ${ }^{1}$, Fengyan Liang ${ }^{1}$ and \\ Sidong Li $^{1}$ \\ 1 Faculty of Chemistry and Environmental Science, Guangdong Ocean University, Zhanjiang 524088, China; \\ 17875128648@163.com (D.Z.); zhangly175@163.com (L.Z.); smelilst@163.com (S.L.); \\ yaner204126@163.com (F.L.); sidongligdou@163.com (S.L.) \\ 2 Southern Marine Science and Engineering Guangdong Laboratory (Zhanjiang), Zhanjiang 524088, China \\ * Correspondence: huzhangqyx@126.com; Tel.: +86-759-238-3300
}

Received: 18 October 2020; Accepted: 4 November 2020; Published: 9 November 2020

\begin{abstract}
Uncontrolled massive hemorrhage is one of the principal causes of death in trauma emergencies. By using catechol-modified chitosan (CS-C) as the matrix material and $\beta$ glycerol phosphate $(\beta-\mathrm{GP})$ as a thermo-sensitive agent, chitosan-based thermo-sensitive hydrogel loading oyster peptides (CS-C/OP/ $\beta-\mathrm{GP})$ were prepared at physiological temperature. The hemostatic performance of CS-C/OP/ $\beta$-GP hydrogel was tested in vivo and in vitro, and its biological safety was evaluated. The results showed that the in vitro coagulation time and blood coagulation index of CS-C/OP/ $\beta$-GP hydrogel were better than those of a commercial gelatin sponge. Notably, compared with the gelatin sponge, $\mathrm{CS}-\mathrm{C} / \mathrm{OP} / \beta$-GP hydrogel showed that the platelet adhesion and erythrocyte adsorption rates were $38.98 \%$ and $95.87 \%$ higher, respectively. Additionally, the hemostasis time in mouse liver injury was shortened by $19.5 \%$, and the mass of blood loss in the mouse tail amputation model was reduced by $18.9 \%$. The safety evaluation results demonstrated that CS-C/OP/ $\beta$-GP had no cytotoxicity to L929 cells, and the hemolysis rates were less than $5 \%$ within $1 \mathrm{mg} / \mathrm{mL}$, suggesting good biocompatibility. In conclusion, our results indicate that CS-C/OP/ $\beta-\mathrm{GP}$ is expected to be a promising dressing in the field of medical hemostasis.
\end{abstract}

Keywords: chitosan; oyster peptides; hydrogel; hemostasis

\section{Introduction}

Rapid hemostasis in emergencies has great clinical significance for patients with massive and potentially fatal hemorrhage caused by war, operations, accidents, or hematologic disease [1]. Hemostasis is an important step in emergency medical treatment [2]. At present, many kinds of hemostatic materials are available on the market. While they have obvious hemostatic effects, their shortcomings are considerable; for example, collagen dressings have poor tissue adhesion [3]; porous zeolite releases heat after absorbing water in the blood, which may lead to wound inflammation [4]; and carboxymethyl gauze cannot be degraded on the wound surface, which can create scars following removal [5].

As a natural polycation polysaccharide prepared by chitin deacetylation, chitosan is characterized by excellent coagulation, bacteriostasis, a film-forming ability, wound healing promotion, and scar formation inhibition. In addition to these features, it is a multifunctional material with good biocompatibility, no immunogenicity, and no dermal irritation [6-8]. The primary hemostatic mechanism of chitosan is that it carries a small positive charge, promoting red blood cell aggregation and platelet adhesion $[9,10]$. However, the hemostatic effect of chitosan is not sufficient to treat severe bleeding wounds [11]. Many researchers have studied how to improve its hemostatic 
potential. The chemical modification of chitosan and its combination with other active ingredients can enhance the hemostatic effect and achieve rapid hemostasis [12-15]. Cheng et al. [16] prepared a chitosan/gelatin thermo-sensitive hydrogel with $\beta$-glycerophosphate as the thermo-sensitive agent. The blend significantly improved the survival rate of encapsulated adipose-derived stem cells, providing a promising method to accelerate the regeneration of ischemic tissue. Zhao et al. [17] successfully prepared a new type of thermo-sensitive chitosan hydrogel loaded with $\beta$-cyclodextrin and curcumin with an inner porous structure that enables sustained curcumin release. In a rat wound infection model, the hydrogel exhibited a significant hemostatic effect and wound healing ability.

Biological resources are abundant in oceans, and numerous marine products harbor natural active substances with unique structures and powerful functions. Among these, marine active peptides are an essential part of investigations into aquatic active substances. Some evidence suggests that marine active peptides have antibacterial, hemostatic, and wound healing-promoting functions [18-20]. Oyster peptides (OP) from marine organisms are composed of active substances, such as antibacterial peptides, angiotensin I converting enzyme inhibitor peptides, and antioxidant peptides [21,22]. Studies have shown that OP have special biological activities, such as antibacterial, antioxidant, hypoglycemic, anti-aging, and anti-tumor activities [23,24]. OP also display some typical physical and chemical characteristics, such as small molecular weights, easy absorption, and non-toxic and harmless natures [21,22]. Furthermore, due to their abundant nutrition and poor biostability, OP are vulnerable to microorganism attack, leading to the loss of their biological function [25]. On the other hand, $\mathrm{OP}$ are water-soluble and cannot be directly used to stop bleeding. To make full use of the benefits of catechol-functionalized chitosan (CS-C)-based hydrogel and OP to obtain an effective hemostatic dressing, in this study, with CS-C as the matrix material, chitosan-based thermo-sensitive hydrogel loading oyster peptides (CS-C/OP/ $\beta$-GP) were prepared. Furthermore, their hemostatic efficacy and biological safety in vivo and in vitro were investigated.

\section{Materials and Methods}

\subsection{Materials}

Chitosan (DD $\geq 85 \%$ and MW $100 \mathrm{kDa}$ ) was used to prepare CS-C by our laboratory [26]. Oyster peptides (about 45\% total protein content, batch NO. 20181018B) were purchased from Hainan Semnl Biotechnology Co., Ltd. (Hainan, China) and the molecular weight of most peptides (>95\%) was less than $1000 \mathrm{Da}$. The mouse fibroblast cell line L929 was provided by the Kunming Cell Bank of the Chinese Academy of Sciences, Kunming, China and the passage numbers used in the experiment were 3-10. Dulbecco's Modified Eagle Medium (DMEM), fetal bovine serum (FBS), antibiotics (penicillin and streptomycin), trypsin, and PBS $(0.01 \mathrm{M}, \mathrm{pH}=7.4)$ were all purchased from Gibco, Grand Island, NY, USA. Calcein-AM/PI and AnnexinV-FITC/PI kits were commercially obtained from Shanghai Yisheng Biotechnology Co., Ltd. (Shanghai, China). Thiazolyl blue tetrazolium bromide (MTT) and dimethyl sulfoxide were acquired from Shanghai Aladdin Biochemical Technology Co., Ltd. (Shanghai, China). $\beta$-GP and 1\% Triton-X100 were purchased from SIGMA (Milwaukee, Wisconsin, USA). Lactate dehydrogenase (LDH) kits were purchased from Shanghai Yuanye Biotechnology Co., Ltd. (Shanghai, China). All other chemical agents were of analytical grade.

\subsection{Preparation and Characterization of Chitosan-Based Thermo-Sensitive Hydrogel}

CS-C was dissolved in $100 \mathrm{~mL}$ distilled water to obtain a $2 \%$ CS-C aqueous solution, into which $0.1 \mathrm{~g}$ OP was added and mixed. Under stirring, the $30 \% \beta$ sodium glycerophosphate $(\beta-\mathrm{GP})$ solution (volume ratio of CS-C to $\beta$-GP was 8:2) was added dropwise, and then placed in a $37{ }^{\circ} \mathrm{C}$ water bath to produce $\mathrm{CS}-\mathrm{C} / \mathrm{OP} / \beta$-GP thermo-sensitive hydrogel and $\mathrm{CS}-\mathrm{C} / \beta$-GP thermo-sensitive hydrogel without OP.

The samples were sprayed with gold under vacuum, and then placed under a scanning electron microscope (SEM, S-4800, Tokyo, Japan) with a voltage of $10 \mathrm{kV}$. 


\subsection{Determination of Water Absorption}

The hydrogel mass after freeze-drying was recorded as $\mathrm{m}_{1}$. The hydrogel was soaked in distilled water for $10 \mathrm{~min}$ and then taken out, and the free water from the surface of the hydrogel was extracted with filter paper. The hydrogel was weighed again as $\mathrm{m}_{2}$. Tests in each group were repeated three times, and the values were averaged. The calculation equation of water absorption (WA) is as follows:

$$
\mathrm{WA}=\frac{m_{2}-m_{1}}{m_{1}} \times 100 \%,
$$

where WA is the water absorption (\%), and $m_{1}$ and $m_{2}$ are hydrogel masses (g) before and after soaking in water, respectively.

\subsection{In Vitro Hemostasis Evaluation}

\subsubsection{Blood Coagulation Index (BCI)}

New Zealand white rabbits were provided by the Guangdong Medical Laboratory Animal Center, Sanshui base (Certificate No. SCXK 20180002, Foshan, China). New Zealand rabbit blood was collected with evacuated blood tubes (sodium citrate as an anticoagulant to blood ratio of 1:9, v/v) and kept at $4{ }^{\circ} \mathrm{C}$ for use. A $10 \mathrm{mg}$ sample was placed into a beaker in a $37^{\circ} \mathrm{C}$ thermostatic water bath, and $100 \mu \mathrm{L}$ anticoagulated rabbit blood and $20 \mu \mathrm{L} 0.2 \mathrm{~mol} / \mathrm{L} \mathrm{CaCl}_{2}$ solution were then added, followed by $25 \mathrm{~mL}$ distilled water after $5 \mathrm{~min}$. The sample was shaken well at $37^{\circ} \mathrm{C}$ and the absorbance was measured at $545 \mathrm{~nm}$. The control group did not contain samples, and the average value of three samples in each group was measured in parallel.

$$
\mathrm{BCI}=\frac{\mathrm{A}_{\text {sample }}}{\mathrm{A}_{\text {control }}} \times 100 \%,
$$

where $A_{\text {sample }}$ is the absorbance value of each experimental sample and $A_{\text {control }}$ is the absorbance value of the control group without adding the sample.

\subsubsection{In Vitro Coagulation Time}

Samples $\left(10 \mathrm{mg}\right.$ ) were placed into a $2 \mathrm{~mL}$ vial and preheated for $5 \mathrm{~min}$ with a $37^{\circ} \mathrm{C}$ water bath, and $0.5 \mathrm{~mL}$ anticoagulated rabbit blood was added. The mixture was heated in the water bath for $5 \mathrm{~min}$, and then $100 \mu \mathrm{L} 0.1 \mathrm{~mol} / \mathrm{L} \mathrm{CaCl}_{2}$ solution was added. The vial was tilted every $10 \mathrm{~s}$ to observe whether the mixture had coagulated, and the coagulation time was recorded.

\subsubsection{Platelet Adhesion}

According to the method of Ong et al. [27], the samples were cut into $0.4 \mathrm{~cm} \times 0.4 \mathrm{~cm} \times 0.2 \mathrm{~cm}$ pieces and added to $50 \mu \mathrm{L}$ platelet-rich plasma, before being incubated at $37^{\circ} \mathrm{C}$ for $1 \mathrm{~h}$. Then, the samples were washed twice with PBS to remove non-adherent platelets. The control group did not contain the sample. The samples were placed in $1 \%$ Triton-X100 solution at $37^{\circ} \mathrm{C}$ for $1 \mathrm{~h}$ to cleave adherent platelets, and were then detected according to the LDH kit instructions. In order to observe the adhesion state of platelets, the samples were fixed in $2.5 \%$ glutaraldehyde for $30 \mathrm{~min}$, before being dehydrated with 30\%, 40\%, 50\%, 60\%, 70\%, 80\%, 90\%, and 100\% ethanol for 15 min successively; dried naturally; sprayed with gold for sample preparation; and observed and photographed by SEM.

\subsubsection{Erythrocyte Adsorption}

Fresh anticoagulated rabbit blood was centrifuged at $2000 \mathrm{rpm}$ for $15 \mathrm{~min}$ to separate the red blood cells which were diluted to $10 \%$ with PBS. Next, $500 \mu \mathrm{L}$ of the red blood cells was added into the samples of $0.4 \mathrm{~cm} \times 0.4 \mathrm{~cm} \times 0.2 \mathrm{~cm}$ and incubated at $37^{\circ} \mathrm{C}$ for $1 \mathrm{~h}$. The samples were washed twice with PBS to remove non-adherent red blood cells, and then placed in $1 \%$ Triton-X100 solution at $37^{\circ} \mathrm{C}$ for $1 \mathrm{~h}$ to split the adherent red blood cells. Absorbance was measured at $540 \mathrm{~nm}$. The control group did 
not contain the sample, and the blank control group did not contain red blood cells. In order to observe the adsorption state of red blood cells, the samples were fixed in $2.5 \%$ glutaraldehyde for $30 \mathrm{~min}$; dehydrated with 30\%, 40\%, 50\%, 60\%, 70\%, 80\%, 90\%, and 100\% ethanol for $15 \mathrm{~min}$ in turn; and then dried naturally. Following this, the samples were sprayed with gold, observed, and photographed by SEM.

$$
\text { Erythrocyte Adsorption }=\frac{\mathrm{A}_{\text {sample }}}{\mathrm{A}_{\text {control }}} \times 100 \% \text {, }
$$

where $\mathrm{A}_{\text {sample }}$ and $\mathrm{A}_{\text {control }}$ are the absorbance values of the sample and control groups without sample, respectively.

\subsection{Evaluation of Animal Hemostasis}

\subsubsection{Animal Preparation}

Male Kunming mice weighing 30-40 g were purchased from Guangdong Medical Experimental Animal Center (Foshan, China). Before the experiment, they were acclimated in the laboratory for 1 week to adapt to the environment. All the animal experiments were approved by the Animal Care and Use Committee of Guangdong Ocean University, China (SYXK20180147).

\subsubsection{Mouse Liver Hemorrhage}

According to methods in the references [27-29], the mice were anesthetized, and the abdomens were shaved and disinfected with $75 \%$ alcohol. After the abdominal cavity was carefully cut, a liver section was taken out to create a wound about $0.5 \mathrm{~cm}$ long, and bleeding occurred spontaneously for $5 \mathrm{~s}$. The blood was wiped with gauze, and the sample was gently pressed on the wound. The bleeding status of the wound was observed, and the time was recorded when the wound stopped bleeding. The hemostatic dressing was weighed to calculate the amount of blood, and the average value of six parallel experiments was adopted.

\subsubsection{Histological Analysis of the Mouse Liver}

Two hours after hemostasis, liver tissue of the bleeding site was collected, and the hemostatic and blood were removed with normal saline. The tissue was fixed with $4 \%$ glutaraldehyde, embedded in paraffin, sectioned, stained with hematoxylin and eosin (H\&E), and observed under an optical microscope.

\subsubsection{Mouse Tail Amputation Hemorrhage}

The tails of anesthetized mice were sterilized with $75 \%$ alcohol to make the tail hyperemic. Next, $50 \%$ of the tail was cut off and allowed to bleed for $15 \mathrm{~s}$. The tail tissue was put into a small centrifuge tube with the sample so that the wound was completely covered by the sample. The time was recorded when the tail stopped bleeding. The blood was collected with standard medical gauze that was weighed to calculate the blood loss. The average value was acquired after six parallel experiments.

\subsection{Safety Evaluation}

\subsubsection{Cytotoxicity}

The cytotoxicity of hydrogel was assessed using the L929 cell line. L929 cells were cultured in DMEM containing 10\% fetal bovine serum (FBS) and antibiotics (streptomycin $100 \mathrm{U} / \mathrm{mL}$ and penicillin $100 \mathrm{U} / \mathrm{mL}$ ) at $37^{\circ} \mathrm{C}$ under a humidified atmosphere of $95 \%$ air and $5 \% \mathrm{CO}_{2}$. After cell counting, the L929 cell concentration was adjusted to $5 \times 10^{4} / \mathrm{mL}$. The cells were inoculated in a 96-well culture plate and placed in an incubator at $37{ }^{\circ} \mathrm{C}$ with $5 \% \mathrm{CO}_{2}$ for $24 \mathrm{~h}$. Next, they were treated by $50 \mu \mathrm{L}$ DMEM with different concentrations of samples, and the group without samples was the control group. They were further incubated for 24 or $48 \mathrm{~h}$. MTT assays were employed to measure the cell viability. 
A previously described method [30] was adopted to distinguish the dead and alive states of cells. After being cultured in a 24-well culture plate, L929 cells were treated with the samples, and the culture medium was then aspirated and discarded. The cells were washed twice with PBS, and $500 \mu \mathrm{L}$ Calcein-AM/PI solution ( $5 \mu \mathrm{L}$ Calcein AM and $15 \mu \mathrm{L}$ PI in $5 \mathrm{~mL} 1 \times$ assay Buffer) was added. The mixture was stained in the dark for $20 \mathrm{~min}$ and washed once with PBS after the staining solution was discarded, and $500 \mu \mathrm{L}$ culture medium was added. Photos were taken under a fluorescent microscope.

\subsubsection{Apoptosis Experiment}

According to the reference [31], L929 cells were cultured in a 6-well culture plate and digested with trypsin after treatment with the samples, before being centrifuged at $850 \mathrm{rpm}$ for $5 \mathrm{~min}$. The cells were collected and washed twice with pre-cooled PBS, and then centrifuged again. Next, $100 \mu \mathrm{L}$ $1 \times$ Binding Buffer (Yisheng Corporation, Shanghai, China) was used to resuspend the cells, and $5 \mu \mathrm{L}$ Annexin V-FITC and $10 \mu \mathrm{L}$ PI Staining Solution (Yisheng Corporation, Shanghai, China) were added. The mixture was kept in the dark at room temperature for $10 \mathrm{~min}$, and $400 \mu \mathrm{L} 1 \times$ Binding Buffer was added for measuring by flow cytometry.

\subsubsection{Hemolysis Analysis}

Sample solution $(500 \mu \mathrm{L})$ was added into a $1.5 \mathrm{~mL}$ centrifuge tube and placed in a $37^{\circ} \mathrm{C}$ thermostatic water bath for $30 \mathrm{~min}$. Next, $500 \mu \mathrm{L} \%$ red blood cell suspension was added, and the mix was cultivated for $30 \mathrm{~min}$ in a $37^{\circ} \mathrm{C}$ thermostatic water bath. Distilled water was used as a positive control and PBS as a blank control. The test was repeated three times in each group. The mixture was centrifuged at $2000 \mathrm{rpm}$ and $4{ }^{\circ} \mathrm{C}$ for $15 \mathrm{~min}$, and the supernatant was measured at $540 \mathrm{~nm}$ to determine its absorbance and calculate the hemolysis rate. To observe morphological changes in red blood cells after treatment, the centrifuged red blood cells were collected and resuspended with PBS, and the morphology was observed and recorded under an optical microscope. The hemolysis rate was calculated as follows:

$$
\text { Hemolysis rate }(\%)=\frac{H-H_{0}}{H_{100}-H_{0}} \times 100 \%,
$$

where $H, H_{0}$, and $H_{100}$ are the absorbance of the sample group, PBS group, and distilled water group, respectively.

\subsection{Statistical Analysis}

All the data were given as the mean \pm standard deviation $(X \pm S D)$. The data were statistically processed with SPSS 17.0 statistical software (International Business Machines Corporation, Armonk, NY, USA) and analyzed using Student's t-tests. Statistical comparisons were performed by using one-way analysis of variance (ANOVA) to demonstrate differences between groups. Differences were considered significant at ${ }^{*} p<0.05$ and highly significant at ${ }^{* *} p<0.01$.

\section{Results and Discussion}

\subsection{Microstructure of $C S-C / O P / \beta-G P$}

SEM revealed that the hydrogel CS-C/OP/ $\beta$-GP had an even porous network structure similar to the commercial gelatin sponge with an average pore size of 100-200 $\mu \mathrm{m}$ (Figure 1). Its structure enables it to absorb water in large quantities and concentrate blood, thus achieving rapid hemostasis. 


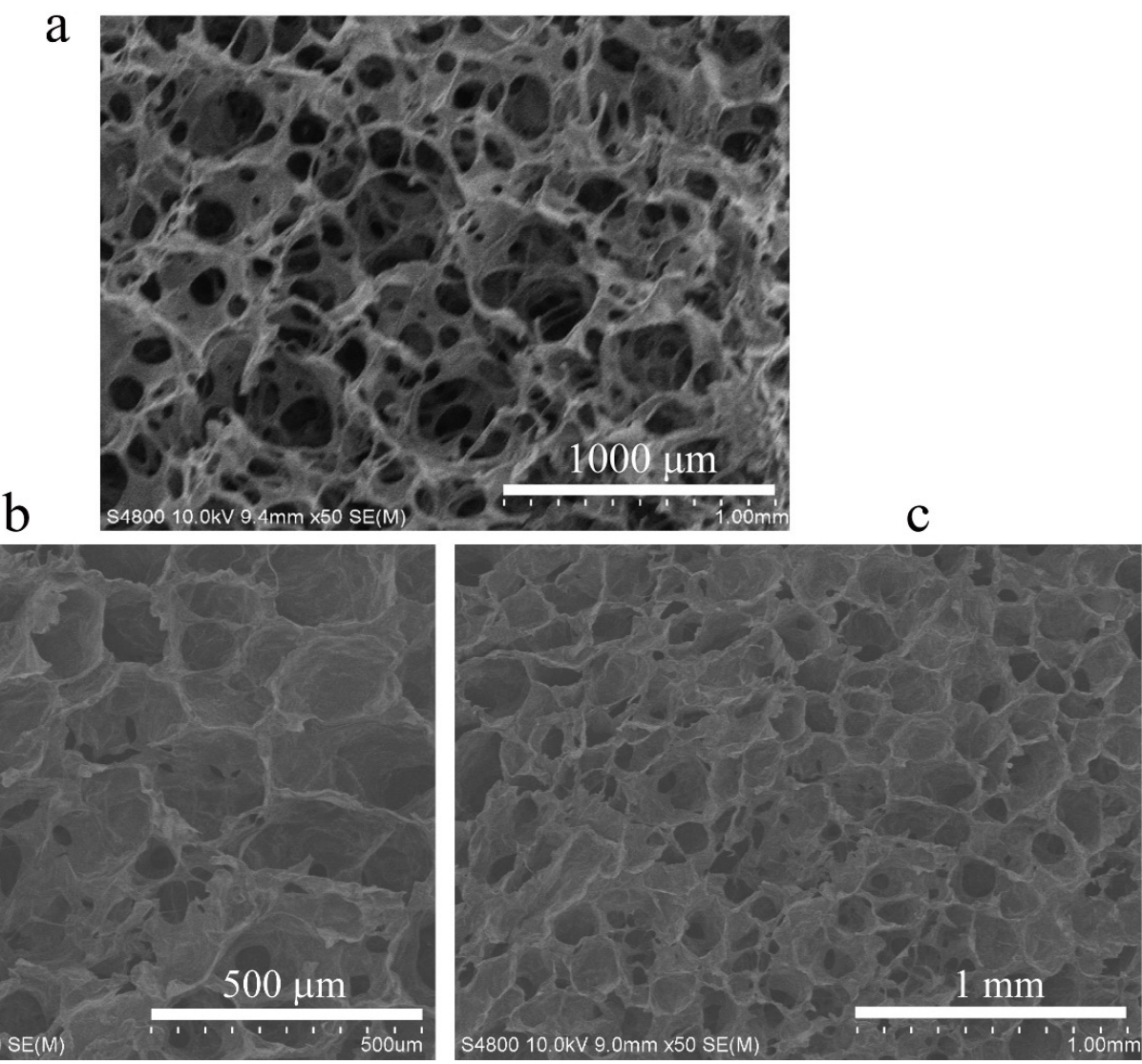

Figure 1. Scanning electron microscope (SEM) images of commercial gelatin sponge (a) and chitosan-based thermo-sensitive hydrogel loading oyster peptide (CS-C/OP/ $\beta-G P)$ hydrogels $(\mathbf{b}, \mathbf{c})$.

\subsection{Water Absorption}

The water absorption capacity is a key parameter for medical hemostatic materials. A high water absorption dressing can absorb exudates to concentrate blood cells and accelerate blood coagulation [20]. Table 1 shows that the water absorption rates of CS-C/ $\beta$-GP and CS-C/OP/ $\beta$-GP hydrogel samples were $554.77 \pm 20.43 \%$ and $584.03 \pm 13.16 \%(n=3)$, respectively, indicating an excellent water absorption capacity. When the hydrogel was applied to wounds, it could absorb a large amount of water from the outflowing blood, leading to blood concentration, thereby achieving rapid hemostasis.

Table 1. Water absorption rate of freeze-dried hydrogels.

\begin{tabular}{cc}
\hline Sample & Water Absorption Rate (\%) \\
\hline CS-C/ $\beta-G P$ & $554.77 \pm 20.43$ \\
CS-C/OP $/ \beta-G P$ & $584.03 \pm 13.16$ \\
\hline
\end{tabular}

\subsection{In Vitro Hemostasis}

\subsubsection{Blood Coagulation Index}

The whole blood coagulation index (BCI) primarily reflects the coagulation effect of dressings. The lower the $\mathrm{BCI}$ is, the better the coagulation effect of the dressing $[27,32,33]$. The BCI of gelatin sponge was $58.25 \pm 5.10 \%(n=3)$, and the values of CS-C/ $\beta$-GP and CS-C/OP/ $\beta$-GP were $57.12 \pm 5.20 \%$ and $45.35 \pm 5.45 \%(n=3)$, respectively. As shown in Figure $2 a$, the BCI of CS-C/ $\beta$-GP was basically the same as that of gelatin sponge, whereas the $\mathrm{BCI}$ of $\mathrm{CS}-\mathrm{C} / \mathrm{OP} / \beta-\mathrm{GP}$ was lower than that of gelatin sponge and CS-C/ $\beta$-GP, and there were significant differences between them $(p<0.05)$, indicating that 
CS-C/ $/$-GP and OP exerted a synergistic effect to promote blood clotting. The results demonstrated that CS-C/OP/ $\beta-G P$ achieved a good coagulation effect.
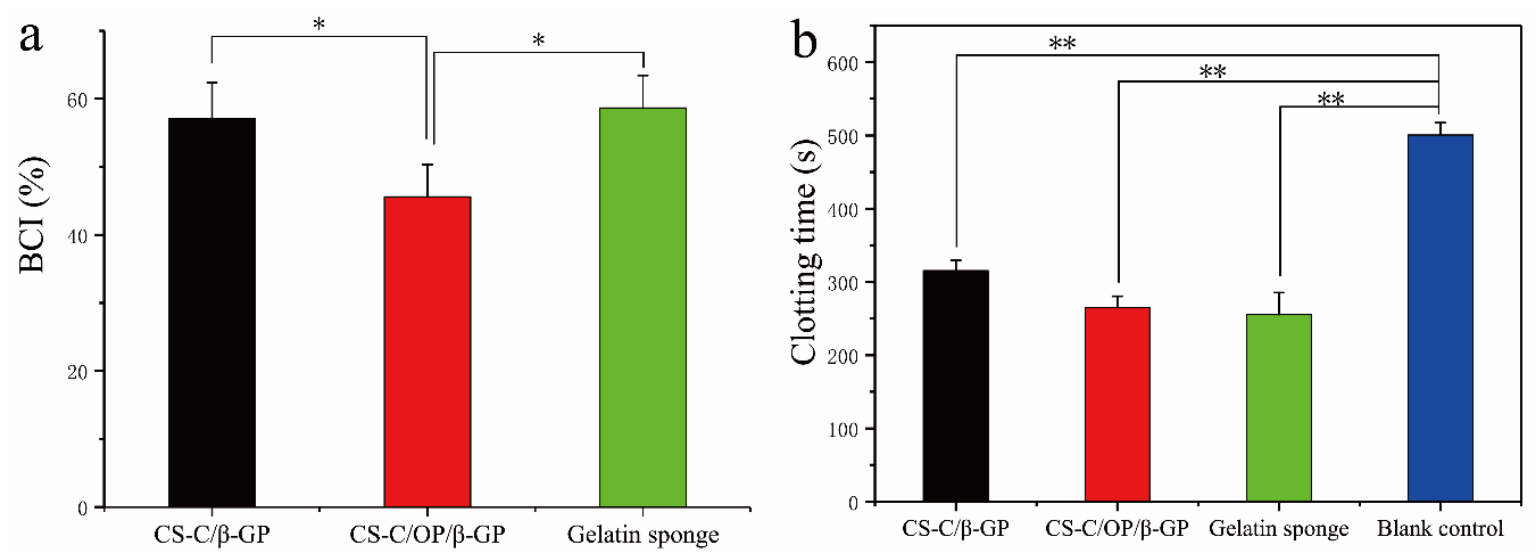

Figure 2. Blood coagulation index (a) and clotting time (b) in vitro, ${ }^{*} p<0.05$ and ${ }^{* *} p<0.01$.

\subsubsection{In Vitro Procoagulant Activity}

The in vitro procoagulant activity is used to evaluate the ability of a dressing to promote blood coagulation after contacting the blood. A shorter coagulation time indicates a better hemostatic effect $[34,35]$. The clotting time of the CS-C/ $\beta-G P, C S-C / O P / \beta-G P$, gelatin sponge, and blank control groups was $315 \pm 14 \mathrm{~s}, 265 \pm 15 \mathrm{~s}, 255 \pm 30 \mathrm{~s}$, and $500 \pm 16 \mathrm{~s}(\mathrm{n}=3)$, respectively (Figure $2 \mathrm{~b}$ ). Compared with the blank control group, both CS-C/ $\beta-$ GP and CS-C/OP/ $\beta-G P$ exhibited highly significant differences $(p<0.01)$. In particular, CS-C/OP/ $\beta-\mathrm{GP}$ had a good coagulation effect equivalent to that of the gelatin sponge, and was significantly different from CS-C/ $\beta-G P(p<0.05)$. The results suggested that $\mathrm{CS}-\mathrm{C} / \mathrm{OP} / \beta-\mathrm{GP}$ could significantly shorten the coagulation time in vitro.

\subsubsection{Platelet Adhesion}

Platelet adhesion of the dressing was calculated by detecting LDH activity after lysing adherent platelets [27]. As shown in Figure $3 \mathrm{a}$, the platelet adsorption rates of CS-C/ $\beta-G P, C S-C / O P / \beta-G P$, and gelatin sponge were $81.82 \pm 2.84 \%, 83.85 \pm 3.58 \%$, and $60.33 \pm 2.51 \%(n=3)$, respectively. The platelet adhesion rate of the CS-C/OP/ $\beta$-GP group was $38.98 \%$ higher than that of the gelatin sponge group $(p<0.05)$. SEM (Figure 3c) showed that more platelets and platelet aggregates were adhered to the CS-C/OP/ $\beta$-GP sample with tighter adhesion compared with the gelatin sponge. This may be because the platelets that adhered to the sample were activated to facilitate the aggregation of more platelets to form clots, and finally achieved rapid hemostasis. These results indicated that CS-C/OP/ $/ \mathrm{G}-\mathrm{GP}$ could adhere to platelets, speed up platelet activation, and facilitate platelet aggregation [35]. 

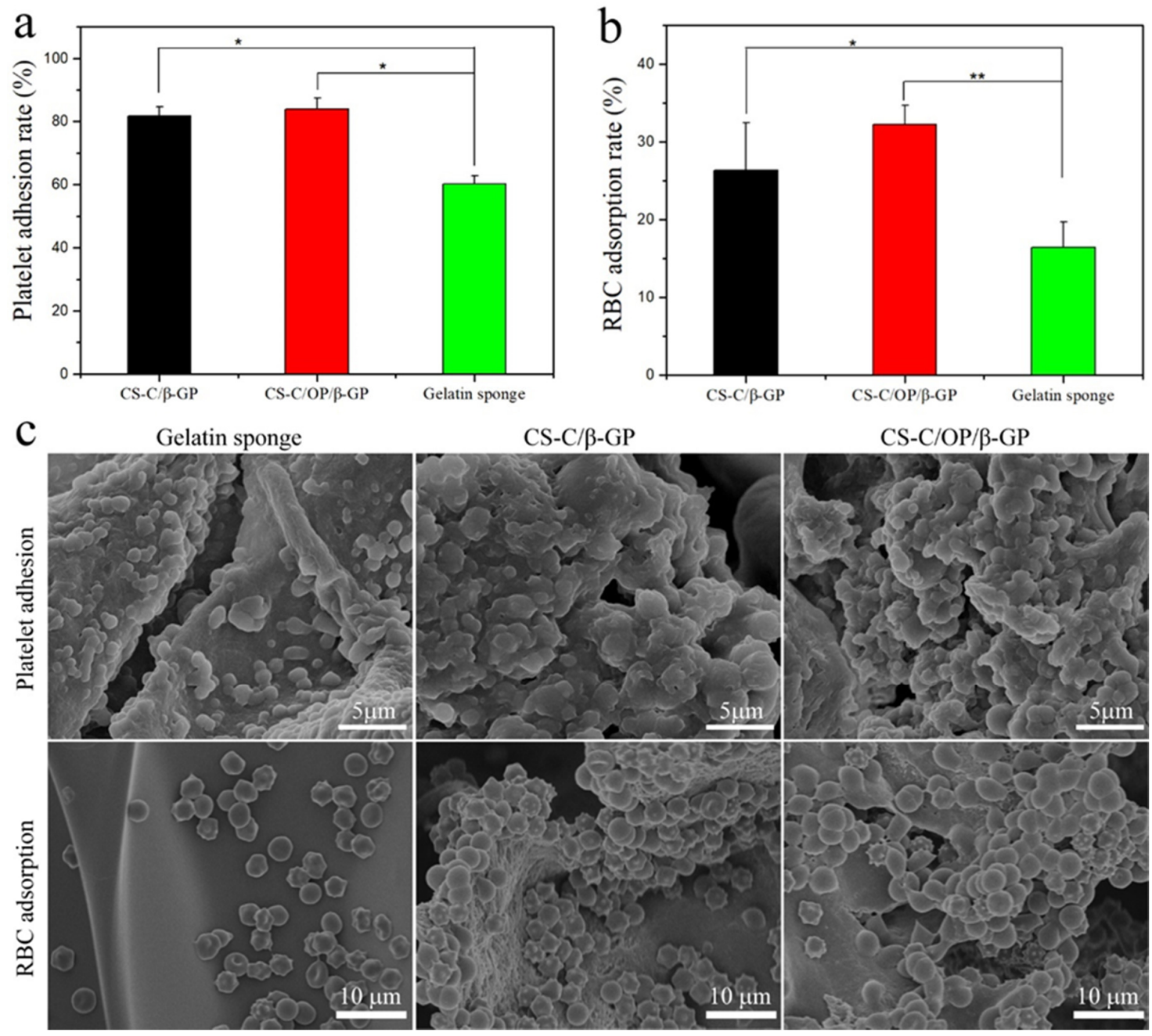

Figure 3. The platelet adhesion rate (a), red blood cell (RBC) adsorption rate (b), and SEM images of red blood cell adsorption and platelet adhesion (c), ${ }^{*} p<0.05$ and ${ }^{* *} p<0.01$.

\subsubsection{Erythrocyte Adsorption}

The ability of dressings to adsorb red blood cells is essential to hemostasis. This can accelerate blood clot formation at the wound, and more importantly, adherent red blood cells can deform and expose the procoagulant phospholipid (phosphatidylserine) on the membrane surface, which is similar to activated platelets [36]. As shown in Figure $3 b$, the erythrocyte adsorption rates of CS-C/ $\beta$-GP, CS-C/OP/ $\beta$-GP, and gelatin sponge were $26.38 \pm 6.11 \%, 32.26 \pm 2.45 \%$, and $16.47 \pm 3.24 \%(n=3)$, respectively. The erythrocyte adsorption rate of CS-C/OP/ $\beta$-GP was $95.87 \%$ higher than that of the gelatin sponge $(p<0.01)$, as well as significantly different from CS-C/ $\beta-G P(p<0.05)$. This may be because the sample dressing has a good water absorption capacity and can promote the adsorption of red blood cells. The red blood cell adsorption results from SEM are shown in Figure 3c. As can be seen in Figure 3c, the surface of the gelatin sponge was smooth, so the adsorbed red blood cells were scattered and their morphology was basically normal, indicating that the erythrocyte adsorption capacity of the gelatin sponge was weak. However, more red blood cells were adsorbed on the surface of CS-C/OP/ $\beta$-GP. Furthermore, it could be seen that there were small tentacles on the red blood cells at the dense places that could connect red blood cells with each other. Due to the porous structure, polycation properties, and good water absorption capacity, CS-C/OP/ $\beta-\mathrm{GP}$ could absorb the water in the plasma to concentrate the blood, adsorb the red blood cells for the wound, and form a blood clot, thus achieving rapid hemostasis [37]. 


\subsection{Hemostasis Activities In Vivo}

\subsubsection{Mouse Liver Hemostasis}

Given the widespread presence of blood vessels in various organs and the unique structure of the liver, it is difficult to ensure that all organs are sutured and deliver effectively applied pressure techniques. Therefore, liver laceration and subsequent blood loss carry a high risk of death [38]. It has been reported that chitosan and catechol-functionalized chitosan can deliver a certain hemostatic effect, by which hydrogel can adhere to the surrounding tissues and rapidly solidify to stop bleeding, thereby promoting hemostasis [6,12]. Therefore, we investigated the hemostatic effect of CS-C/OP/ $\beta-G P$ on a mouse liver laceration. Figure 4 a shows the application of samples in the hemostasis of liver injury and the hemostasis time and liver blood losses are shown in Figure $4 b$,c. The blank control group without any treatment was still bleeding after $3.5 \mathrm{~min}$, while hemostasis was achieved in the sample and gelatin sponge groups within $1.0 \mathrm{~min}$, which indicated a highly significant difference between the sample and blank control groups $(p<0.01)$. Compared with the gelatin sponge, the hemostatic time of CS-C/OP/ $\beta$-GP was $44.6 \pm 2.6 \mathrm{~s}(\mathrm{n}=6)$, so was shortened by $19.5 \%$, which was significant $(p<0.05)$. With regard to blood loss, $\mathrm{CS}-\mathrm{C} / \mathrm{OP} / \beta-\mathrm{GP}$ and gelatin sponge groups displayed no significant difference, but there was a highly significant difference compared to the blank control group $(p<0.01)$. Even without applying pressure, CS-C/OP/ $\beta$-GP hydrogel quickly adhered to the wound tissues to achieve rapid hemostasis. It can be concluded that CS-C/OP/ $\beta$-GP hydrogel had an excellent liver hemostatic effect and greatly reduced the amount of organ bleeding.
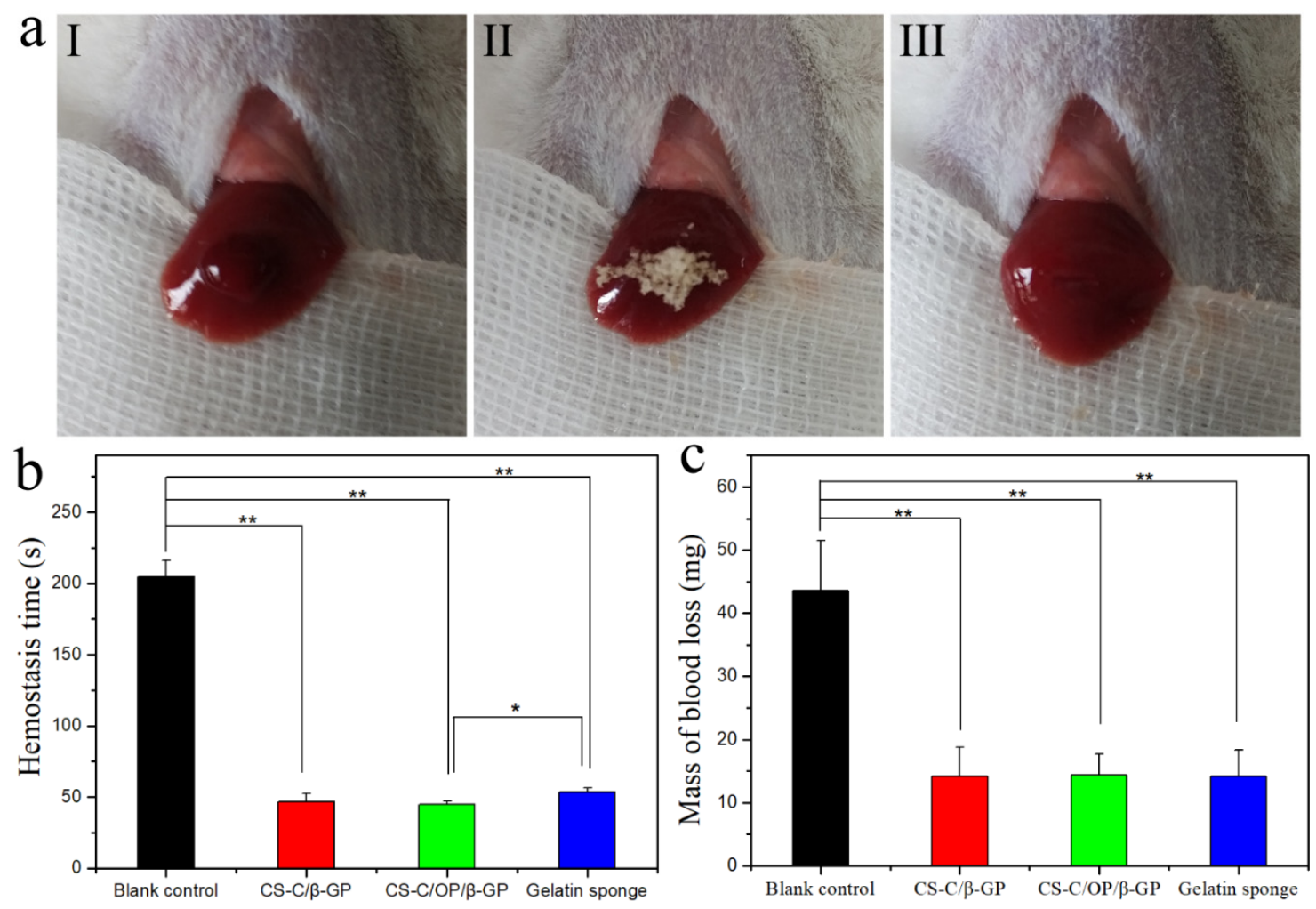

Figure 4. Hemostasis of the liver laceration (a) (I: liver bleeding; II: liver hemostasis; III: wound after hemostasis), hemostasis time (b), and mass of blood loss (c) in a liver injury model, ${ }^{*} p<0.05$ and ** $p<0.01$.

Figure 5 shows the liver tissue pathology after hemostasis. Normal liver parenchyma was seen in both sample groups, the liver lobule structure was well-preserved, and the central vein could be observed in the lobule. Liver cells normally radiate along the central vein, forming a plate 
with the thickness of a single hepatocyte. The sinusoids between the plates were normal in shape, without obvious hyperemia.

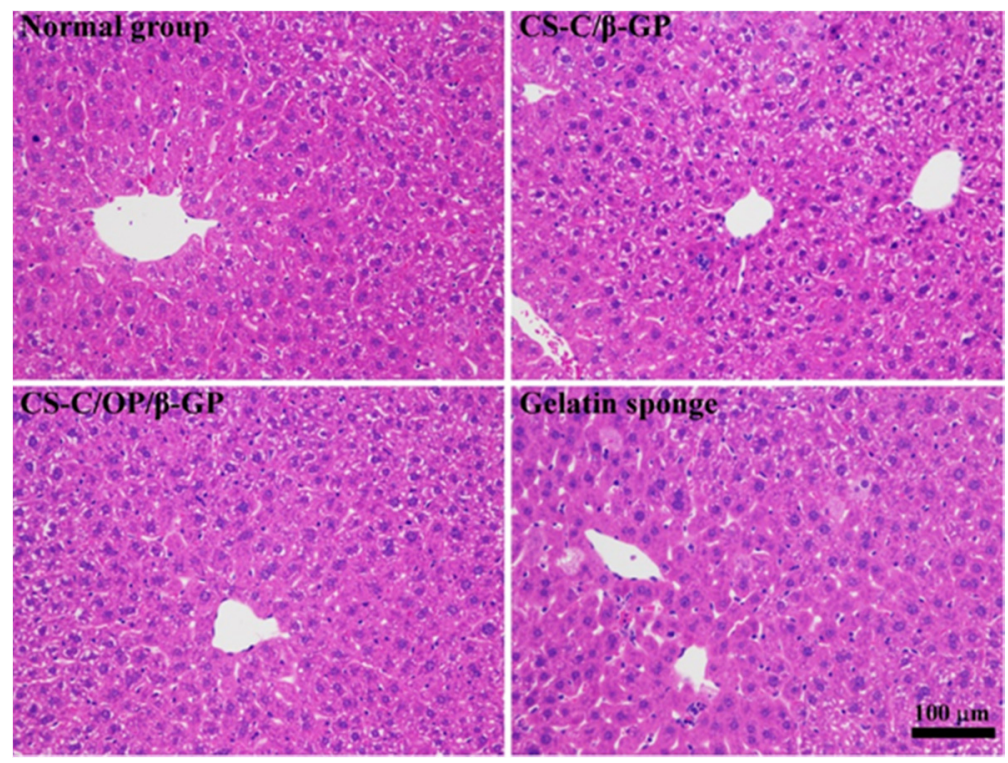

Figure 5. Hematoxylin and eosin (H\&E) stained micrographs of liver tissues.

\subsubsection{Hemostasis of Mouse Tail Amputation}

The hemostatic effect of the CS-C/OP/ $\beta$-GP hydrogel was further evaluated in the mouse tail bleeding model, and the results are shown in Figure 6. Compared with the blank control group, the hemostasis time and mass of blood loss of the gelatin sponge, $C S-C / \beta-G P$, and $C S-C / O P / \beta-G P$ groups were significantly reduced $(p<0.01)$. Furthermore, the hemostasis time of $C S-C / O P / \beta-G P$ hydrogel was not significantly different from the gelatin sponge group, but the mass of blood loss decreased by $18.9 \%$.
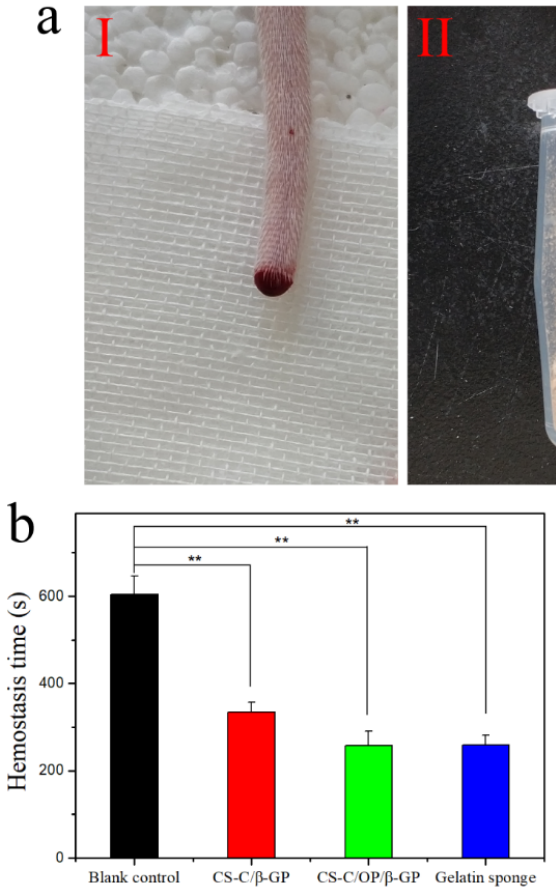
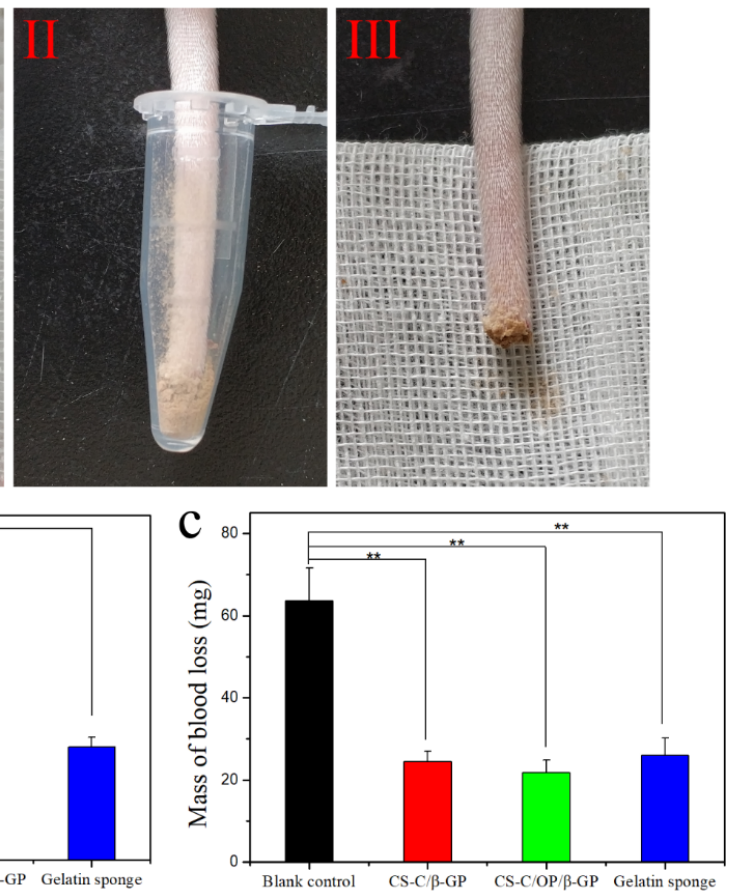

Figure 6. Hemostasis of the tail amputation (a) (I: bleeding; II: hemostasis; III: wound after hemostasis), hemostasis time (b), and mass of blood loss (c) on tail amputation, ${ }^{* *} p<0.01$. 


\subsection{Safety Evaluation}

\subsubsection{Cytotoxicity}

In the early stages of wound healing, fibroblasts play a vital role by actively proliferating, migrating to the wound area, and inducing the synthesis of new extracellular matrix and thick actin myofibroblasts [39]. The L929 fibroblast cell line has been extensively employed as an in vitro model of skin cell behavior $[15,40]$. L929 cells treated by CS-C/OP/ $\beta-G P$ hydrogel with different concentrations were cultured for 24 and $48 \mathrm{~h}$, and the cell viability results are shown in Figure 7 . Compared with the control group, CS-C/OP/ $\beta-\mathrm{GP}$ with different concentrations had a higher cell viability, indicating that $\mathrm{CS}-\mathrm{C} / \mathrm{OP} / \beta-\mathrm{GP}$ was non-toxic to $\mathrm{L} 929$ cells. Compared with $\mathrm{CS}-\mathrm{C} / \beta-\mathrm{GP}$, the cell viability of CS-C/OP/ $\beta$-GP at different concentrations was higher, and it exhibited a dose-dependent and time-dependent manner, which could be reasonably explained by the fact that OP delivered some nutrients to promote cell proliferation.

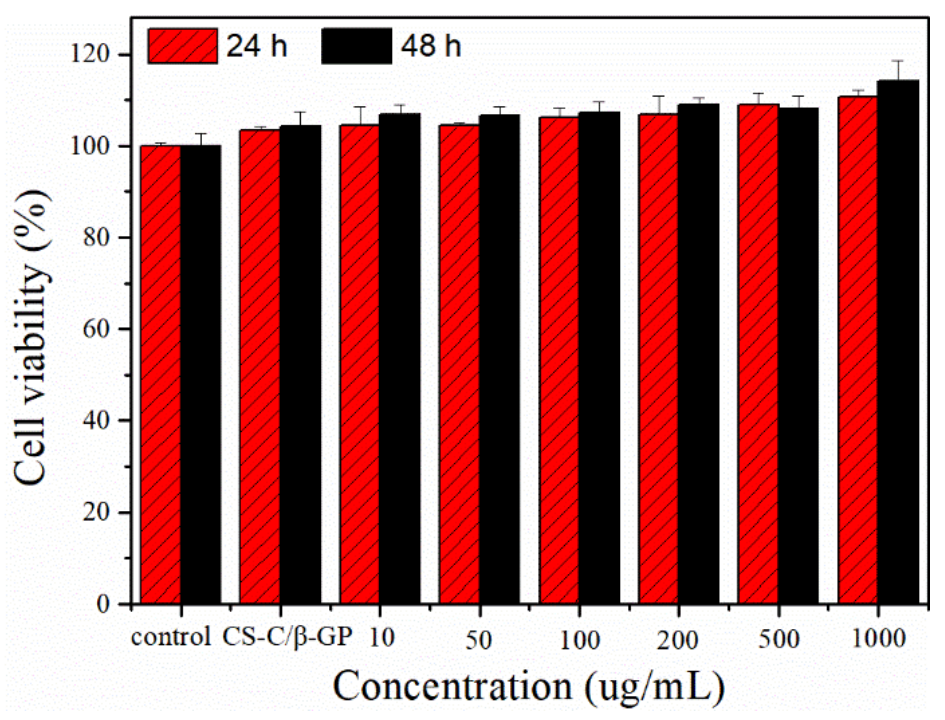

Figure 7. Effects of CS-C/OP/ $/$-GP on the L929 cell viability.

The cytotoxicity of the samples in L929 cells was further evaluated by the double staining of Calcein-AM/PI. The green fluorescent signal represents living cells, and the red signal indicates dead cells [41]. As shown in Figure 8, there was no significant difference between the control group and the samples at $24 \mathrm{~h}$, whereas $\mathrm{CS}-\mathrm{C} / \beta-\mathrm{GP}$ and $\mathrm{CS}-\mathrm{C} / \mathrm{OP} / \beta$-GP displayed strong green fluorescence compared with the control group at $48 \mathrm{~h}$. From the pictures of the samples, except for the individual dead cells, most of the cells maintained a normal spindle shape and had a higher cell density and even distribution. These results indicated that $\mathrm{L} 929$ cells could grow normally in the presence of CS-C/OP/ $\beta$-GP.

L929 cell apoptosis was quantitatively analyzed by flow cytometry with the Annexin FITC/PI double staining method. As shown in Figure 9, the apoptosis rates of the control group were $7.6 \%$ and $6.4 \%$ at 24 and $48 \mathrm{~h}$, respectively. After $24 \mathrm{~h}$ treatment, the apoptosis rates of CS-C/ $\beta$-GP and CS-C/OP/ $\beta$-GP were $4.5 \%$ and $5.8 \%$, respectively. After $48 \mathrm{~h}$, those were $5.5 \%$ and $6.2 \%$, respectively. Compared with the control group, the apoptosis rates of CS-C/ $\beta-G P$ and CS-C/OP/ $\beta-G P$ hydrogel groups were lower, but there were no significant differences among them. The results indicated that CS-C/OP/ $\beta$-GP had no significant effects on L929 cell apoptosis. 

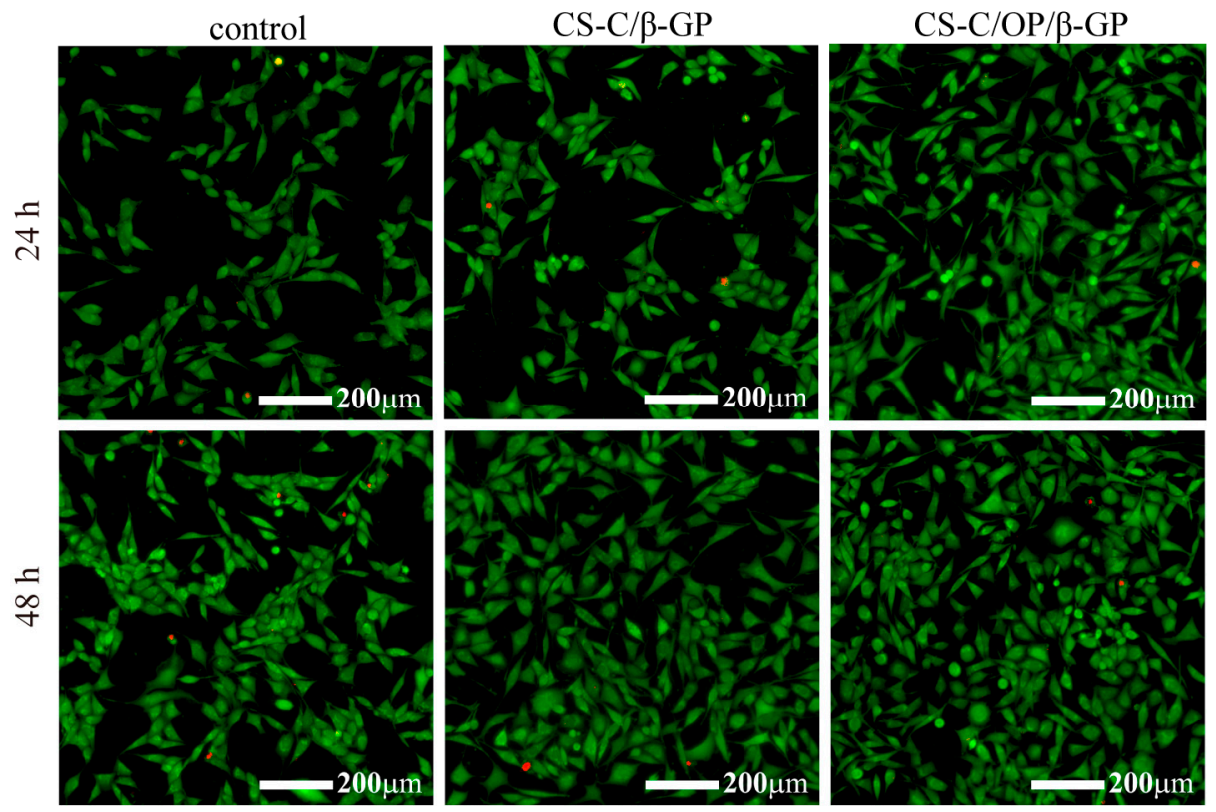

Figure 8. Calcein-AM/PI double staining for L929 cells.
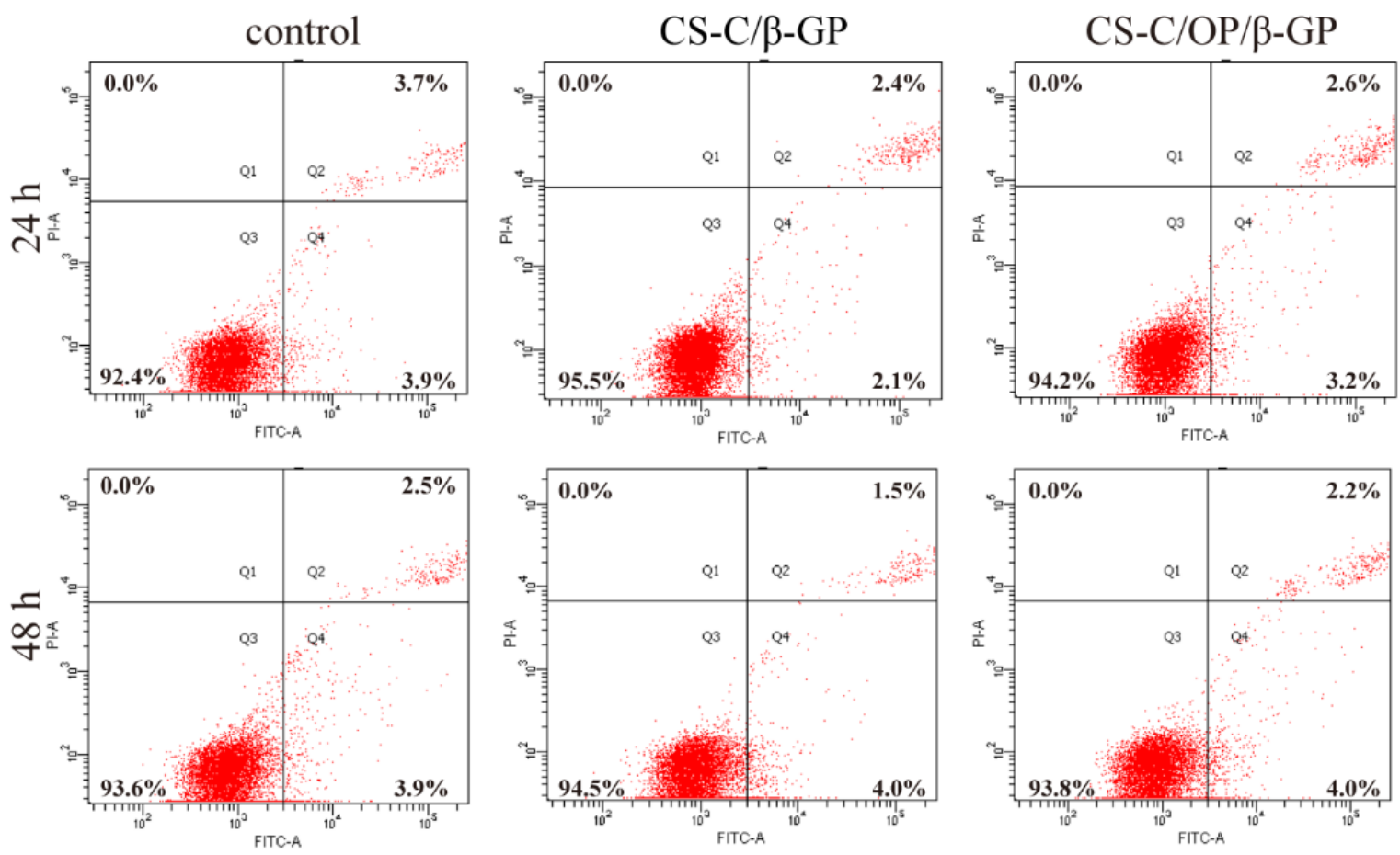

Figure 9. Analysis of L929 cell apoptosis by flow cytometry.

\subsubsection{Hemolysis Rate}

A low hemolysis rate of a material suggests that it causes limited damage to red blood cells and has better blood compatibility [42]. As shown in Figure 10a, the hemolysis rates of hydrogel samples increased slightly with increasing concentrations. However, within $1000 \mu \mathrm{g} / \mathrm{mL}$, the hemolysis rates were all less than $5 \%$, indicating good blood compatibility. From Figure 10b, the supernatants of red blood cell suspensions were clear or light pink, indicating no or slight hemolysis. The morphological changes of treated red blood cells are shown in Figure 10c. It can be seen that the cells in the negative control group (PBS) were intact and disc-shaped, while those in the positive control group (water) 
were broken. After treatment with different concentrations of hydrogels, the morphology of red blood cells was similar to that of the PBS group, showing that there was no obvious hemolytic effect. This demonstrated that hydrogel samples within $1000 \mu \mathrm{g} / \mathrm{mL}$ did not cause hemolysis and had good blood compatibility.
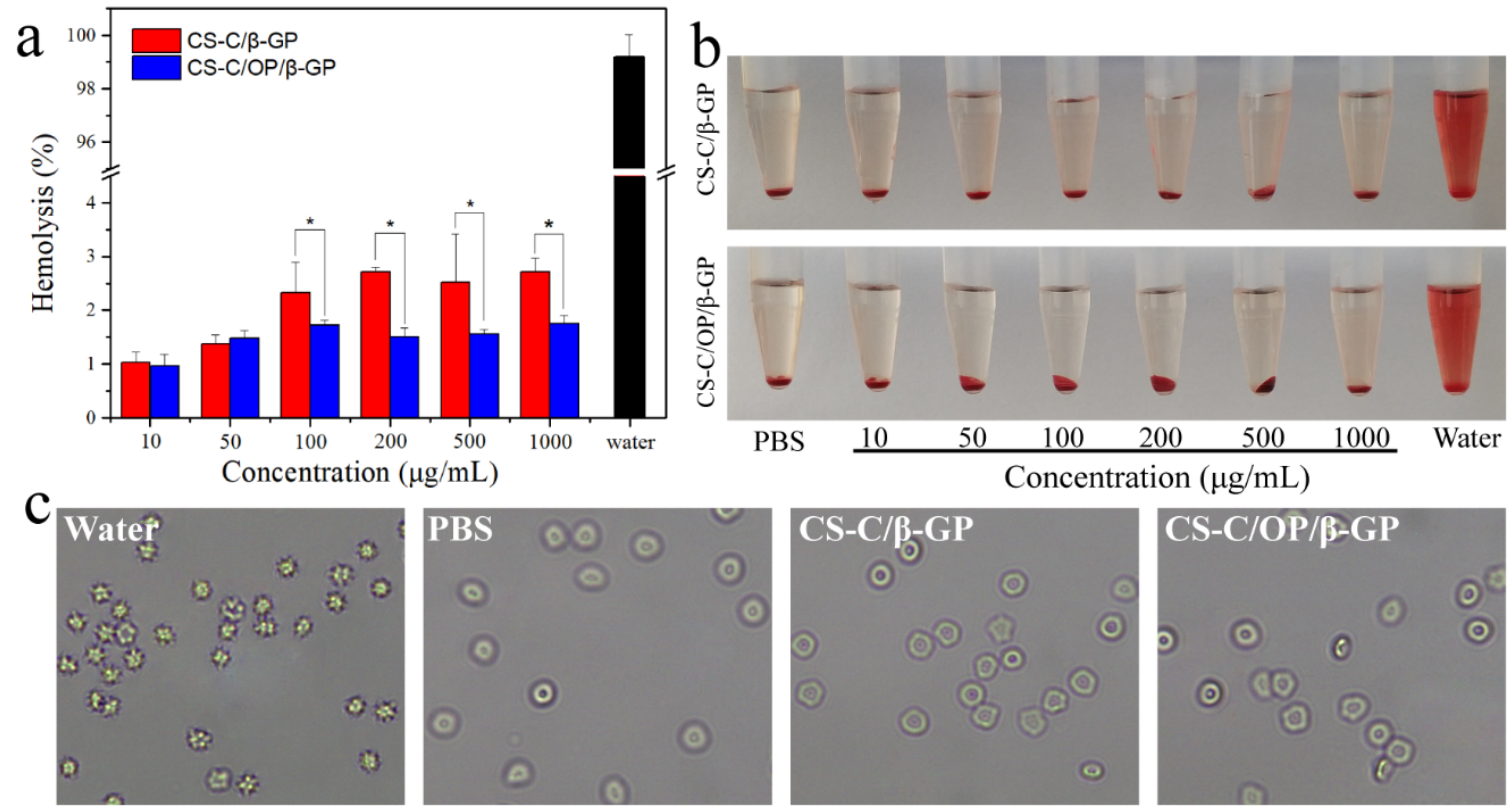

Figure 10. (a) Hemolysis ratio, (b) RBC suspension solutions, and (c) microscopy of RBCs treated with samples, ${ }^{*} p<0.05$.

\section{Conclusions}

With its porous three-dimensional network structure, $\mathrm{CS}-\mathrm{C} / \mathrm{OP} / \beta-\mathrm{GP}$ thermo-sensitive hydrogel can quickly absorb water and concentrate blood. In vitro testing revealed that CS-C/OP/ $\beta-G P$ hydrogel adsorbed a large number of red blood cells to form blood clots and promoted blood clotting. Meanwhile, CS/OP/ $\beta$-GP hydrogel adhered to platelets, accelerated platelet activation, facilitated platelet aggregation, and led to rapid hemostasis. In mouse hemorrhagic models, CS-C/OP/ $\beta$-GP hydrogel exerted a sealing effect on the wound surface with a short hemostasis time and less blood loss than the medical gelatin sponge, thus achieving rapid hemostasis. The rapid and effective hemostasis of CS-C/OP/ $\beta$-GP hydrogel may be attributed to the three-dimensional porous structure of the material, the multiple coagulation pathways of chitosan independent of the classical coagulation cascade, and the activation of endogenous coagulation factors by oyster peptides. As for the specific hemostasis mechanisms, this still remains a great challenge. Safety evaluations confirmed that CS-C/OP/ $\beta-G P$ hydrogel was not cytotoxic and had desirable blood compatibility. In conclusion, CS-C/OP/ $\beta-G P$ hydrogel is expected to be developed as a hemostatic dressing.

Author Contributions: Conceptualization, Z.H. and D.Z.; investigation and methodology, D.Z. and S.L. (Sitong Lu); validation, S.L. (Sitong Lu) and L.Z.; software and formal analysis, L.Z. and F.L.; writing-review and editing, D.Z. and Z.H.; funding acquisition, Z.H. and S.L. (Sidong Li); visualization and supervision, S.L. (Sidong Li); All authors have read and agreed to the published version of the manuscript.

Funding: The authors gratefully acknowledge the financial support by the Guangdong Provincial Natural Science Foundation of China (2016A030308009), Project of Science and Technology Plan of Guangdong Province (2015A020216019), Project of Science and Technology Plan of Zhanjiang (2019A01017 and 2020A01026), Project of Enhancing School with Innovation of Guangdong Ocean University (2017KTSCX090), and Postgraduate Education Innovation Program of Guangdong Ocean University (201926 and 201927).

Conflicts of Interest: The authors declare no conflict of interest. 


\section{References}

1. Hickman, D.A.; Pawlowski, C.L.; Sekhon, U.D.S.; Marks, J.; Gupta, A.S. Biomaterials and Advanced Technologies for Hemostatic Management of Bleeding. Adv. Mater. 2018, 30, 1700859. [CrossRef] [PubMed]

2. Kauvar, D.S.; Lefering, R.; Wade, C.E. Impact of hemorrhage on trauma outcome: An overview of epidemiology, clinical presentations, and therapeutic considerations. J. Trauma. 2006, 60, S3-S11. [CrossRef] [PubMed]

3. Han, W.; Zhou, B.; Yang, K.; Xiong, X.; Luan, S.; Wang, Y.; Xu, Z.; Lei, P.; Luo, Z.; Gao, J.; et al. Biofilm-inspired adhesive and antibacterial hydrogel with tough tissue integration performance for sealing hemostasis and wound healing. Bioact. Mater. 2020, 5, 768-778. [CrossRef] [PubMed]

4. Seyednejad, H.; Imani, M.; Jamieson, T.; Seifalian, A.M. Topical haemostatic agents. Br. J. Surg. 2008, 95, 1197-1225. [CrossRef] [PubMed]

5. Demirekin, Z.B.; Sezer, U.A.; Karatopuk, D.U.; Sezer, S. Development of Metal Ion Binded Oxidized Regenerated Cellulose Powder as Hemostatic Agent: A Comparative Study with in Vivo Performance. Ind. Eng. Chem. Res. 2015, 54, 4906-4914. [CrossRef]

6. Kumar, M.N.V.R.; Muzzarelli, R.A.A.; Muzzarelli, C.; Sashiwa, H.; Domb, A.J. Chitosan chemistry and pharmaceutical perspectives. Chem. Rev. 2004, 104, 6017-6084. [CrossRef]

7. Gu, R.; Sun, W.; Zhou, H.; Wu, Z.; Meng, Z.; Zhu, X.; Tang, Q.; Dong, J.; Dou, G. The performance of a fly-larva shell-derived chitosan sponge as an absorbable surgical hemostatic agent. Biomaterials 2010, 31, 1270-1277. [CrossRef]

8. $\quad$ Ouyang, Q.Q.; Hu, Z.; Lin, Z.P.; Quan, W.Y.; Deng, Y.F.; Li, S.D.; Li, P.W.; Chen, Y. Chitosan hydrogel in combination with marine peptides from tilapia for burns healing. Int. J. Biol. Macromol. 2018, 112, 1191-1198. [CrossRef]

9. Pusateri, A.E.; Holcomb, J.B.; Kheirabadi, B.S.; Alam, H.B.; Wade, C.E.; Ryan, K.L. Making sense of the preclinical literature on advanced hemostatic products. J. Trauma 2006, 60, 674-682. [CrossRef]

10. Hu, Z.; Zhang, D.Y.; Lu, S.T.; Li, P.W.; Li, S.D. Chitosan-Based Composite Materials for Prospective Hemostatic Applications. Mar. Drugs 2018, 16, 273. [CrossRef]

11. Achneck, H.E.; Sileshi, B.; Jamiolkowski, R.M.; Albala, D.M.; Shapiro, M.L.; Lawson, J.H. A Comprehensive Review of Topical Hemostatic Agents Efficacy and Recommendations for Use. Ann. Surg. 2010, 251, 217-228. [CrossRef] [PubMed]

12. Ryu, J.H.; Lee, Y.; Kong, W.H.; Kim, T.G.; Park, T.G.; Lee, H. Catechol-functionalized chitosan/pluronic hydrogels for tissue adhesives and hemostatic materials. Biomacromolecules 2011, 12, 2653-2659. [CrossRef]

13. Hattori, H.; Amano, Y.; Nogami, Y.; Takase, B.; Ishihara, M. Hemostasis for Severe Hemorrhage with Photocrosslinkable Chitosan Hydrogel and Calcium Alginate. Ann. Biomed. Eng. 2010, 38, 3724-3732. [CrossRef] [PubMed]

14. Shi, X.; Fang, Q.; Ding, M.; Wu, J.; Ye, F.; Lv, Z.; Jin, J. Microspheres of carboxymethyl chitosan, sodium alginate and collagen for a novel hemostatic in vitro study. J. Biomater. Appl. 2016, 30, 1092-1102. [CrossRef]

15. Zhao, X.; Wu, H.; Guo, B.; Dong, R.; Qiu, Y.; Ma, P.X. Antibacterial anti-oxidant electroactive injectable hydrogel as self-healing wound dressing with hemostasis and adhesiveness for cutaneous wound healing. Biomaterials 2017, 122, 34-47. [CrossRef]

16. Cheng, N.C.; Lin, W.J.; Ling, T.Y.; Young, T.H. Sustained release of adipose-derived stem cells by thermosensitive chitosan/gelatin hydrogel for therapeutic angiogenesis. Acta Biomater. 2017, 51, $258-267$. [CrossRef] [PubMed]

17. Zhao, Y.; Liu, J.G.; Chen, W.M.; Yu, A.X. Efficacy of thermosensitive chitosan/beta-glycerophosphate hydrogel loaded with beta-cyclodextrin-curcumin for the treatment of cutaneous wound infection in rats. Exp. Ther. Med. 2018, 15, 1304-1313. [CrossRef]

18. Zhang, Y.; Cui, P.; Wang, Y.; Zhang, S. Identification and bioactivity analysis of a newly identified defensin from the oyster Magallana gigas. Dev. Comp. Immunol. 2018, 85, 177-187. [CrossRef]

19. Hu, Z.; Yang, P.; Zhou, C.; Li, S.; Hong, P. Marine Collagen Peptides from the Skin of Nile Tilapia (Oreochromis niloticus): Characterization and Wound Healing Evaluation. Mar. Drugs 2017, 15, 102. [CrossRef]

20. Ouyang, Q.; Hou, T.; Li, C.; Hu, Z.; Liang, L.; Li, S.; Zhong, Q.; Li, P. Construction of a composite sponge containing tilapia peptides and chitosan with improved hemostatic performance. Int. J. Biol. Macromol. 2019, 139, 719-729. [CrossRef] 
21. Wang, Q.; Li, W.; He, Y.; Ren, D.; Kow, F.; Song, L.; Yu, X. Novel antioxidative peptides from the protein hydrolysate of oysters (Crassostrea talienwhanensis). Food Chem. 2014, 145, 991-996. [CrossRef]

22. Zhang, Z.; Zhou, F.; Liu, X.; Zhao, M. Particulate nanocomposite from oyster (Crassostrea rivularis) hydrolysates via zinc chelation improves zinc solubility and peptide activity. Food Chem. 2018, 258, $269-277$. [CrossRef]

23. Xu, D.; Lin, F.; Zhu, X.Y.; Liu, W.Y.; Chen, X.Y.; Feng, J.Q.; Fan, A.Q.; Cai, M.Y.; Xu, Y.J. Immunomodulatory effect of oyster peptide on immunosuppressed mice. Beijing Da Xue Xue Bao Yi Xue Ban 2016, 48, 392-397. [PubMed]

24. Asha, K.K.; Remya Kumari, K.R.; Ashok Kumar, K.; Chatterjee, N.S.; Anandan, R.; Mathew, S. Sequence Determination of an Antioxidant Peptide Obtained by Enzymatic Hydrolysis of Oyster Crassostrea madrasensis (Preston). Int. J. Pept. Res. Ther. 2016, 22, 421-433. [CrossRef]

25. Raftery, R.M.; Woods, B.; Marques, A.L.P.; Moreira-Silva, J.; Silva, T.H.; Cryan, S.A.; Reis, R.L.; O’Brien, F.J. Multifunctional biomaterials from the sea: Assessing the effects of chitosan incorporation into collagen scaffolds on mechanical and biological functionality. Acta Biomater. 2016, 43, 160-169. [CrossRef]

26. Zhang, D.Y.; Hu, Z.; Lu, S.T.; Li, S.D.; Yang, Z.M.; Li, P.W. Preparation and characterization of catechol-functionalized chitosan thermosensitive hydrogels. IOP Conf. Ser. Mater. Sci. Eng. 2019, 629, 012038. [CrossRef]

27. Ong, S.Y.; Wu, J.; Moochhala, S.M.; Tan, M.H.; Lu, J. Development of a chitosan-based wound dressing with improved hemostatic and antimicrobial properties. Biomaterials 2008, 29, 4323-4332. [CrossRef]

28. Pan, M.; Tang, Z.; Tu, J.; Wang, Z.; Chen, Q.; Xiao, R.; Liu, H. Porous chitosan microspheres containing zinc ion for enhanced thrombosis and hemostasis. Mater. Sci. Eng. C Mater. Biol. Appl. 2018, 85, 27-36. [CrossRef]

29. Li, J.; Wu, X.; Wu, Y.; Tang, Z.; Sun, X.; Pan, M.; Chen, Y.; Li, J.; Xiao, R.; Wang, Z.; et al. Porous chitosan microspheres for application as quick in vitro and in vivo hemostat. Mater. Sci. Eng. C Mater. Biol. Appl. 2017, 77, 411-419. [CrossRef]

30. Zhu, M.; Liu, P.; Shi, H.; Tian, Y.; Ju, X.; Jiang, S.; Li, Z.; Wu, M.; Niu, Z. Balancing antimicrobial activity with biological safety: Bifunctional chitosan derivative for the repair of wounds with Gram-positive bacterial infections. J. Mater. Chem. B 2018, 6, 3884-3893. [CrossRef]

31. Feng, C.; Wang, Z.; Jiang, C.; Kong, M.; Zhou, X.; Li, Y.; Cheng, X.; Chen, X. Chitosan/o-carboxymethyl chitosan nanoparticles for efficient and safe oral anticancer drug delivery: In vitro and in vivo evaluation. Int. J. Pharm. 2013, 457, 158-167. [CrossRef]

32. Lan, G.; Lu, B.; Wang, T.; Wang, L.; Chen, J.; Yu, K.; Liu, J.; Dai, F.; Wu, D. Chitosan/gelatin composite sponge is an absorbable surgical hemostatic agent. Colloids Surf. B Biointerfaces 2015, 136, 1026-1034. [CrossRef] [PubMed]

33. Chan, L.W.; Kim, C.H.; Wang, X.; Pun, S.H.; White, N.J.; Kim, T.H. PolySTAT-modified chitosan gauzes for improved hemostasis in external hemorrhage. Acta Biomater. 2016, 31, 178-185. [CrossRef]

34. Shih, M.-F.; Shau, M.-D.; Chang, M.-Y.; Chiou, S.-K.; Chang, J.-K.; Cherng, J.-Y. Platelet adsorption and hemolytic properties of liquid crystal/composite polymers. Int. J. Pharm. 2006, 327, 117-125. [CrossRef]

35. Hong, J.; Larsson, A.; Ekdahl, K.N.; Elgue, G.; Larsson, R.; Nilsson, B. Contact between a polymer and whole blood: Sequence of events leading to thrombin generation. J. Lab. Clin. Med. 2001, 138, 139-145. [CrossRef] [PubMed]

36. Fischer, T.H.; Valeri, C.R.; Smith, C.J.; Scull, C.M.; Merricks, E.P.; Nichols, T.C.; Demcheva, M.; Vournakis, J.N. Non-classical processes in surface hemostasis: Mechanisms for the poly-N-acetyl glucosamine-induced alteration of red blood cell morphology and surface prothrombogenicity. Biomed. Mater. 2008, 3, 051009. [CrossRef]

37. Dowling, M.B.; Smith, W.; Balogh, P.; Duggan, M.J.; MacIntire, I.C.; Harris, E.; Mesar, T.; Raghavan, S.R.; King, D.R. Hydrophobically-modified chitosan foam: Description and hemostatic efficacy. J. Surg. Res. 2015, 193, 316-323. [CrossRef]

38. Behrens, A.M.; Sikorski, M.J.; Li, T.; Wu, Z.J.; Griffith, B.P.; Kofinas, P. Blood-aggregating hydrogel particles for use as a hemostatic agent. Acta Biomater. 2014, 10, 701-708. [CrossRef]

39. Li, W.; Fan, J.H.; Chen, M.; Guan, S.X.; Sawcer, D.; Bokoch, G.M.; Woodley, D.T. Mechanism of human dermal fibroblast migration driven by type I collagen and platelet-derived growth factor-BB. Mol. Biol. Cell 2004, 15, 294-309. [CrossRef] 
40. Wang, D.; Xu, P.; Wang, S.; Li, W.; Liu, W. Rapidly curable hyaluronic acid-catechol hydrogels inspired by scallops as tissue adhesives for hemostasis and wound healing. Eur. Polym. J. 2020, 134, 109763. [CrossRef]

41. Yuan, M.; Bi, B.; Huang, J.; Zhuo, R.; Jiang, X. Thermosensitive and photocrosslinkable hydroxypropyl chitin-based hydrogels for biomedical applications. Carbohydr. Polym. 2018, 192, 10-18. [CrossRef]

42. Liu, J.-Y.; Li, Y.; Hu, Y.; Cheng, G.; Ye, E.; Shen, C.; Xu, F.-J. Hemostatic porous sponges of cross-linked hyaluronic acid/cationized dextran by one self-foaming process. Mater. Sci. Eng. C Mater. Biol. Appl. 2018, 83, 160-168. [CrossRef]

Publisher's Note: MDPI stays neutral with regard to jurisdictional claims in published maps and institutional affiliations.

(C) 2020 by the authors. Licensee MDPI, Basel, Switzerland. This article is an open access article distributed under the terms and conditions of the Creative Commons Attribution (CC BY) license (http://creativecommons.org/licenses/by/4.0/). 